\title{
Ethanol Electrooxidation on Pt with Lanthanum Oxide as Cocatalyst in a DAFC
}

\author{
T. A. B. Santoro, ${ }^{1,2}$ A. Oliveira Neto, ${ }^{2}$ C. A. L. G. de O. Forbicini, ${ }^{2}$ M. Linardi, ${ }^{2}$ \\ J. L. Rodríguez, ${ }^{1}$ and E. Pastor ${ }^{1}$ \\ ${ }^{1}$ Departamento de Química Física, Instituto Universitario de Materiales y Nanotecnología, Universidad de La Laguna, \\ C/Astrofísico Francisco Sánchez s/n, 38071 La Laguna, Spain \\ ${ }^{2}$ Instituto de Pesquisas Energéticas e Nucleares (IPEN), CNEN-SP, Avenida Professor Lineu Prestes 2242, Cidade Universitária, \\ 05508-900 São Paulo, SP, Brazil
}

Correspondence should be addressed to T. A. B. Santoro, thaisabsantoro@yahoo.com.br

Received 1 May 2011; Revised 1 November 2011; Accepted 24 November 2011

Academic Editor: Newton Pimenta Neves Jr.

Copyright ( $\odot 2012$ T. A. B. Santoro et al. This is an open access article distributed under the Creative Commons Attribution License, which permits unrestricted use, distribution, and reproduction in any medium, provided the original work is properly cited.

Electrocatalytic activity toward ethanol electrooxidation of Pt particles in PtLa/C catalysts with different Pt: La ratios has been studied with different electrochemical and spectroscopic techniques, and the results were compared to those of Pt/C catalyst. Significant enhancement in the electrocatalytic activity has been achieved by depositing the Pt particles with lanthanum oxides/hydroxides using an alcohol reduction method. Compared to Pt/C catalyst, $\mathrm{PtLa} / \mathrm{C}$ materials exhibit a lower onset potential and a higher electron-transfer rate constant for the investigated reaction. These studies illustrate the possibility of utilizing Pt/C with La oxides/ hidroxides as electrocatalyst for direct alcohol fuel cells (DAFCs).

\section{Introduction}

In catalysis, numerous applications can be found for lanthanum oxide. It is used as support for metals that catalyze reactions such as methanol decomposition, ammonia oxidation, and methane dry reforming [1-4]. It is also recognized as an active and selective catalyst for several processes [5-7]. It has been shown that lanthanum oxides can substantially modify the chemical behaviour of highly dispersed metal catalysts [6]. In this system, several chemical species are present such as $\mathrm{La}_{2} \mathrm{O}_{3}$ or $\mathrm{La}(\mathrm{OH})_{3}[8]$, which could be implied in the electrooxidation of alcohols like methanol or ethanol, for example.

In the past decades, direct alcohol fuel cells (DAFCs) have received much attention due to their possible applications in transportation and portable electronic devices [9-15]. Methanol or ethanol can be directly used as fuel in DAFCs without external reformer. Ethanol has higher energy density compared with methanol $[15,16]$ and it is more attractive as fuel for DAFCs: it is safer and can be produced in great quantities from biomass. However, the ethanol electrooxidation has slow reaction kinetics that is still the main problem for its direct application in an ethanol fuel cell (DEFC). A lot of work has been done with the purpose to prepare catalysts with sufficiently high catalytic activity and $\mathrm{CO}$ tolerance for ethanol electrooxidation. It is accepted that the coexistence of some metal oxides with Pt can improve the catalytic activity of Pt-based catalysts for this reaction.

In the present work, the effect of the addition of La oxides/hidroxides to $\mathrm{Pt} / \mathrm{C}$ is investigated for ethanol electrooxidation [16]. PtLa/C catalyst powders with different compositions were prepared and compared to $\mathrm{Pt} / \mathrm{C}$. X-ray diffraction (XRD), cyclic voltammetry (CV), steady-state polarization experiments, and Fourier transform IR spectroscopy (FTIRS) were employed as characterization techniques to provide information on the physicochemical properties as well as on the catalytic activity of these materials towards the electrochemical reactions of ethanol.

\section{Experimental}

$\mathrm{PtLa} / \mathrm{C}$ with different $\mathrm{Pt}: \mathrm{La}$ atomic ratios and $\mathrm{Pt} / \mathrm{C}$ catalysts were prepared by an alcohol reduction process in alkaline 
environment (KOH/Pt: La molar ratio of 8) using Vulcan $\mathrm{XC} 72 \mathrm{R}$ as support. Metal precursors were $\mathrm{H}_{2} \mathrm{PtCl}_{6} \cdot 6 \mathrm{H}_{2} \mathrm{O}$ (Aldrich) and $\mathrm{LaCl}_{3} \cdot \mathrm{xH}_{2} \mathrm{O}$ (Aldrich), and ethylene glycol (Merck) was employed as solvent and reducing agent [1719]. The reduction potential of $\mathrm{La}$ is about $3.5 \mathrm{~V}$ more negative than that of $\mathrm{Pt}[20]$. Therefore, it is not possible to reduce $\mathrm{La}$ (III) ions to $\mathrm{La}^{0}$ in the conditions of the chosen methodology. Thus, in alkaline medium La(III) ions are deposited as lanthanum oxide and/or hydroxide. On the other hand, Pt (IV) ions can be reduced by ethylene glycol to metallic Pt nanoparticles, which are placed on the carbon support. Characterization of prepared materials by XRD and transmission electron microscopy (TEM) has been described in a previous work where it was proved that $\mathrm{La}$ is deposited in the form of oxides and hydroxides by this procedure [21]. The diffractograms of PtLa/C electrocatalysts showed the peaks characteristic of fcc $\mathrm{Pt}$ and the presence of the contributions of $\mathrm{La}_{2} \mathrm{O}_{3}$ at $26^{\circ}, 29^{\circ}, 34^{\circ}$, and $56^{\circ}$ (JPDF 000-831354) and those of $\mathrm{La}(\mathrm{OH})_{3}$ at $27^{\circ}, 31^{\circ}$, and $43^{\circ}$ (JPDF 00075-1900) [21, 22].

Dispersive X-ray (EDX) analysis using a scanning electron microscope Philips XL30 with a $20 \mathrm{keV}$ electron beam and provided with EDAX DX-4 microanalyser was used to establish the real composition of the materials investigated in the present paper.

The electrochemical measurements for the ethanol oxidation reaction were carried out with a three-electrode flow cell. A hydrogen electrode in the electrolyte solution (RHE) was used as reference and a glassy carbon as counter electrode. The working electrode was prepared with $40 \mu \mathrm{L}$ of a homogeneous mixture of $4 \mathrm{mg}$ of powder electrocatalyst, ultrasonically dispersed in $1 \mathrm{~mL}$ of Milli-Q ultrapure water, and $38 \mu \mathrm{L}$ of Nafion (Aldrich, 5 wt.\%) [23]. This ink was deposited onto a glassy carbon polished surface disc, with geometric area of $0.28 \mathrm{~cm}^{2}$, and dried in $\mathrm{N}_{2}$ atmosphere before its utilization.

Electrochemical experiments were performed in a $1 \mathrm{~mol} \mathrm{~L}^{-1} \mathrm{CH}_{3} \mathrm{CH}_{2} \mathrm{OH}+0.5 \mathrm{~mol} \mathrm{~L}^{-1} \mathrm{H}_{2} \mathrm{SO}_{4}$ solution for both $\mathrm{PtLa} / \mathrm{C}$ and $\mathrm{Pt} / \mathrm{C}$ electrocatalysts. Cyclic voltammograms (CVs) were recorded in the $0.05-0.90 \mathrm{~V}$ potential range at $0.01 \mathrm{Vs}^{-1}$ and the current-time curves at a constant potential of $0.55 \mathrm{~V}$. Activation pretreatment by potential cycling between 0.05 and $0.40 \mathrm{~V}$ in the base electrolyte $\left(\mathrm{H}_{2} \mathrm{SO}_{4}\right.$ $0.5 \mathrm{~mol} \mathrm{~L}^{-1}$ ) was applied until a stabilized CV was achieved (the upper potential was set to $0.40 \mathrm{~V}$ in order to avoid $\mathrm{La}$ dissolution from the alloy). A potentiostat/galvanostat Autolab PGSTAT30 was used for these studies.

Electroactive area was calculated from the hydrogen adsorption/desorption region assuming $0.210 \mathrm{mC} / \mathrm{cm}^{2}$ for the oxidation of an $\mathrm{H}$ adsorbed monolayer. Density current values in the paper are calculated with respect to the electroactive areas.

Fourier transform IR spectroscopy (FTIRS) experiments were carried out with a Bruker Vector 22 spectrometer equipped with an MCT (mercury cadmium telluride) detector. A small glass flow cell with a $60^{\circ} \mathrm{CaF}_{2}$ prism at its bottom was employed. For each spectrum, 128 interferograms were collected at selected potentials with a resolution of $8 \mathrm{~cm}^{-1}$, by applying $0.05 \mathrm{~V}$ single potential steps from a reference
TABLE 1: Pt: La ratios from EDX analysis and current density from chronoamperometric curves obtained at $0.55 \mathrm{~V}$.

\begin{tabular}{lcc}
\hline Electrocatalysts & Atomic ratios $(\mathrm{Pt}: \mathrm{La})$ & $\mathrm{CV}_{0.55}\left(\mathrm{~mA} \mathrm{~cm}^{-2}\right)$ \\
\hline PtLa 30:70 & $37: 63$ & 0.288 \\
PtLa $50: 50$ & $57: 43$ & 0.213 \\
Pt & - & 0.092 \\
\hline
\end{tabular}

potential $(0.05 \mathrm{~V})$ in the positive going direction. Spectra are represented as the ratio $R / R_{0}$, where $R$ and $R_{0}$ are the reflectance at the sample and reference spectra, respectively [11]. In this way, positive bands represent the loss and negative bands the gain of species at the sampling potential.

The working electrodes for FTIRS consist of a thin layer of a certain amount of the metal/C catalysts deposited over a polycrystalline gold disk. The geometric area of the disk was $0.85 \mathrm{~cm}^{2} .40 \mu \mathrm{L}$ of the homogeneous mixture of powder electrocatalyst was pipetted on the top of the gold disk and dried at ambient temperature. The electrolyte was $0.1 \mathrm{~mol} \mathrm{~L}^{-1} \mathrm{HClO}_{4}$ containing $1.0 \mathrm{~mol} \mathrm{~L}^{-1}$ of ethanol.

\section{Results and Discussion}

The real compositions of the catalysts were established from EDX analysis and results are summarized in Table 1. The measured atomic ratios of $\mathrm{PtLa} / \mathrm{C}$ were close to nominal ones, so it can be deduced that Pt and La oxides/hydroxides were successfully loaded on the carbon support without metal loss.

The cyclic voltammograms for ethanol oxidation on $\mathrm{PtLa} / \mathrm{C}$ and $\mathrm{Pt} / \mathrm{C}$ electrodes in $1.0 \mathrm{~mol} \mathrm{~L}^{-1} \mathrm{CH}_{3} \mathrm{CH}_{2} \mathrm{OH}+$ $0.5 \mathrm{~mol} \mathrm{~L}^{-1} \mathrm{H}_{2} \mathrm{SO}_{4}$ solution at room temperature are given in Figure 1. It can be observed that the CVs exhibit the irreversible nature of the ethanol electrooxidation that is characteristic of Pt-based catalysts. The onset for ethanol electrooxidation occurs at approximately $0.50 \mathrm{~V}$ but a shift to more negative potentials is clearly apparent when introducing $\mathrm{La}$ species in the material, especially in the case of the PtLa/C (30:70) catalyst. Moreover, different maximum current densities are achieved during the positive potential scan. The highest current density is apparent for PtLa/C (30:70) catalysts, and it is about twice that obtained for Pt/C. The PtLa/C $(50: 50)$ electrocatalyst also increases the catalytic activity, by a factor of 1.5 when compared to $\mathrm{Pt} / \mathrm{C}$. Therefore, the activity order towards ethanol electrooxidation can be established as follows: PtLa/C $(30: 70)>\mathrm{PtLa} / \mathrm{C}(50: 50)>\mathrm{Pt} / \mathrm{C}$. Then, the content of La oxides/hydroxides in the PtLa/C catalysts affects the catalytic activity for ethanol electrochemical oxidation allowing the oxidation at lower potentials and increasing the current density values.

Considering that ethanol does not react on La oxides/ hidroxides, from these data it can be concluded that the addition of La oxides/hydroxides significantly increases the catalytic activity of Pt towards ethanol electrooxidation. Probably this result is related to the improvement of the kinetics of $\mathrm{CO}$ and other adspecies oxidation on Pt through 


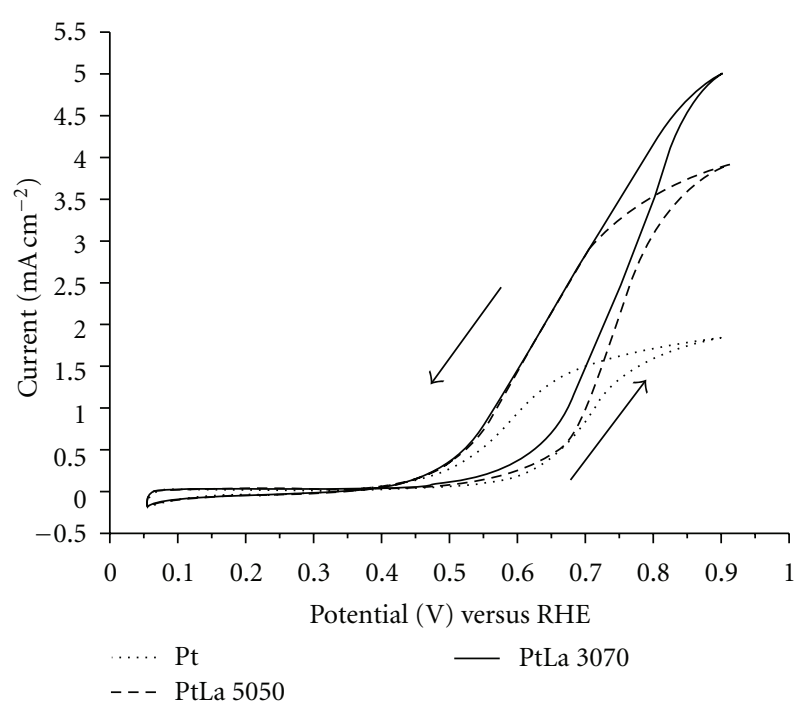

FIgURE 1: Cyclic voltammograms for ethanol electrooxidation on $\mathrm{Pt} / \mathrm{C}, \mathrm{PtLa} / \mathrm{C}(50: 50)$, and $\mathrm{PtLa} / \mathrm{C}(30: 70)$ electrocatalysts in $1.0 \mathrm{~mol} \mathrm{~L}^{-1} \mathrm{CH}_{3} \mathrm{CH}_{2} \mathrm{OH}+0.5 \mathrm{~mol} \mathrm{~L}^{-1} \mathrm{H}_{2} \mathrm{SO}_{4}$ in the 0.05 to $0.90 \mathrm{~V}$ potential range at room temperature. Scan rate: $0.010 \mathrm{Vs}^{-1}$.

a bifunctional mechanism [24] (as no alloy is formed in these materials according to previous results in [21]).

To compare the cyclic voltammetric and the potentiostatic responses of the electrocatalysts, chronoamperometric curves in $1.0 \mathrm{~mol} \mathrm{~L}^{-1} \mathrm{CH}_{3} \mathrm{CH}_{2} \mathrm{OH}+0.5 \mathrm{~mol} \mathrm{~L}^{-1} \mathrm{H}_{2} \mathrm{SO}_{4}$ were recorded at $0.55 \mathrm{~V}$ during $900 \mathrm{~s}$. Results are given in Figure 2 and stable current density values summarized in Table 1 . The same trend previously established from the CVs is observed.

All current-time curves display an initial fast current drop in the first 90 seconds followed by a slower rise only apparent for PtLa materials. This observation could be explained assuming that a fast poisoning of the Pt surface takes place in the first instants, but, in the presence of La oxides/ hydroxides, slower oxidation of the poisons occurs to a certain extent at $0.55 \mathrm{~V}$. Thus, the current increases until achieving a stable value when the concurrence between both processes (poisoning and oxidation of the adspecies) acquires the equilibrium. In other words, $\mathrm{PtLa} / \mathrm{C}$ electrocatalysts are more resistant to the poisoning caused by ethanol intermediate adspecies causing a significant increase of performance with the augment of La oxides/hidroxides content. This behaviour could be attributed to the oxophilic character of $\mathrm{La}$ in $\mathrm{La}(\mathrm{OH})_{2}$ and $\mathrm{La}_{2} \mathrm{O}_{3}[25]$.

Using $\mathrm{CeO}_{2}$, an increment in performance was also described by Xua and coworkers [24]. They attributed the activity enhancement for alcohol electrooxidation after the addition of $\mathrm{CeO}_{2}$ to the Pt catalysts to the bifunctional mechanism, where the formation of chemisorbed oxygen species was favoured by $\mathrm{CeO}_{2}$ and promotes the oxidation of adsorbed carbon monoxide on the surface of Pt. Neto et al. [26] observed an improvement in ethanol electrooxidation using nanocrystalline $\mathrm{Pt} / \mathrm{CeO}_{2}$ composite electrodes. From the studies of carbon monoxide oxidation over $\mathrm{Pt}-\mathrm{CeO}_{2}$ and $\mathrm{Pt}-$ $\mathrm{SnO}_{2}$, these authors associated the increase in the activity with the oxygen spillover from the oxides onto the Pt sites

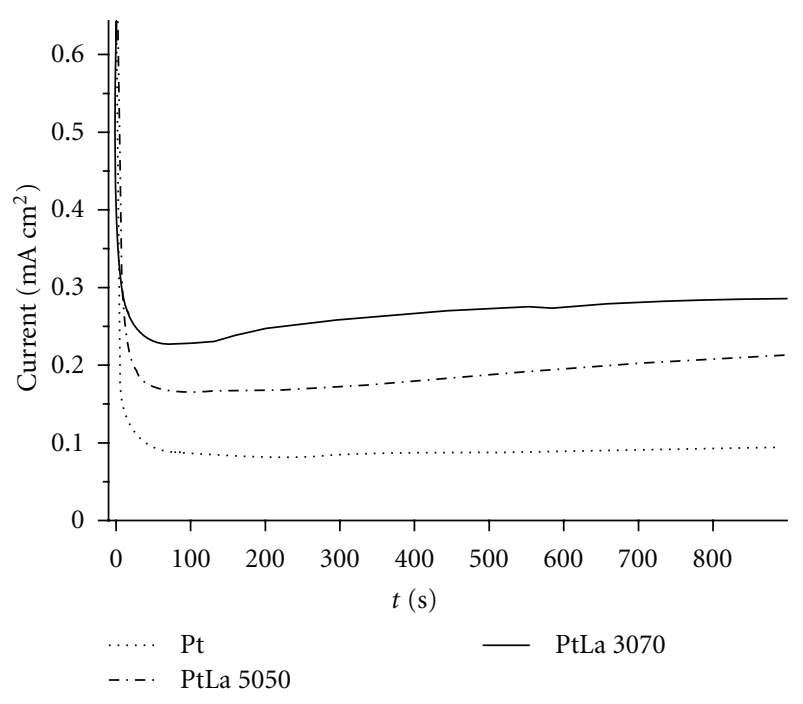

Figure 2: Current-time curves at $0.55 \mathrm{~V}$ in $1.0 \mathrm{~mol} \mathrm{~L}^{-1} \mathrm{CH}_{3} \mathrm{CH}_{2} \mathrm{OH}$ $+0.5 \mathrm{~mol} \mathrm{~L}^{-1} \mathrm{H}_{2} \mathrm{SO}_{4}$ solution for Pt/C, PtLa/C (50:50) and PtLa/C $(30: 70)$ electrocatalysts.

[26]. In a similar way, it is also possible that, in our case, the release of oxygen from the surface of La oxides/hidroxides particles contributes to facilitating the oxidation of adsorbed $\mathrm{CO}$ and other intermediate species on the Pt surface.

To provide complementary information on the electrochemical oxidation of ethanol, Fourier transform IR spectroscopy (FTIRS) was employed as catalyst characterization technique. According to Iwasita et al. [27], possible products during ethanol electrooxidation are $\mathrm{CO}_{2}$, acetaldehyde, and acetic acid, although ethyl acetate could also be produced by the reaction of acetic acid with ethanol. Figure 3 presents the IR spectra acquired with p-polarized light in $1.0 \mathrm{~mol} \mathrm{~L}^{-1}$ $\mathrm{CH}_{3} \mathrm{CH}_{2} \mathrm{OH}+0.5 \mathrm{~mol} \mathrm{~L}^{-1} \mathrm{H}_{2} \mathrm{SO}_{4}$ solution during the progressive ethanol electrooxidation from $0.05 \mathrm{~V}$ up to $0.90 \mathrm{~V}$ for $\mathrm{PtLa} / \mathrm{C}(50: 50)$ catalyst. $\mathrm{HClO}_{4}$ was used instead of $\mathrm{H}_{2} \mathrm{SO}_{4}$ in order to avoid the bands related to the adsorption of sulphate/bisulphate species.

In Figure 3, the growing in $\mathrm{CO}_{2}$ production is indicated by the asymmetric stretching vibration band at $2343 \mathrm{~cm}^{-1}$. The positive going features at 2983 and $2901 \mathrm{~cm}^{-1}$ correspond to $\mathrm{CH}_{3} \mathrm{CH}_{2} \mathrm{OH}$ and indicate the consumption of the alcohol in the thin layer. At $0.80 \mathrm{~V}$ all other contributions in the spectrum are well developed. At $1715 \mathrm{~cm}^{-1}$, the stretching band of the carbonyl group $(\mathrm{C}=\mathrm{O})$ is observed. Both acetaldehyde and acetic acid could be responsible for this band, so it is not appropriated for identification purposes [27]. As the potential is stepped to more positive values, two other negative features at 1354 and $1278 \mathrm{~cm}^{-1}$ appear in the spectrum, parallel to the carbonyl band. According to Iwasita et al. [27], the spectrum of pure acetic acid presents in this region two bands due to the coupled $\mathrm{C}-\mathrm{O}$ stretching and $\mathrm{OH}$ deformation.

These results confirm that $\mathrm{CO}_{2}$ and acetic acid are produced during ethanol oxidation. On the other hand, the identification of acetaldehyde in the presence of comparable quantities of acetic acid is difficult. The characteristic features 


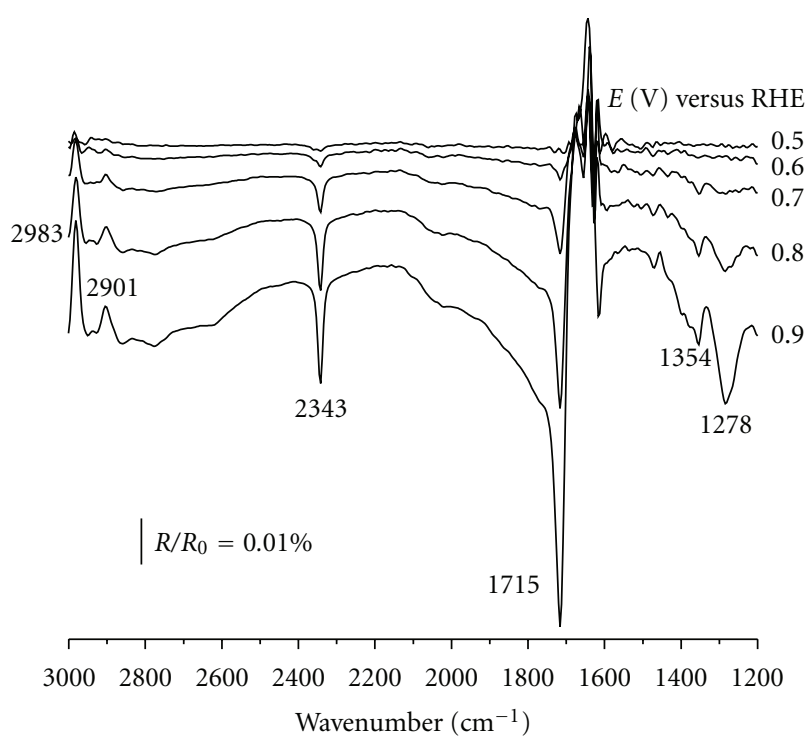

FIGURE 3: In situ FTIR spectra obtained in $1.0 \mathrm{~mol} \mathrm{~L}^{-1} \mathrm{CH}_{3} \mathrm{CH}_{2} \mathrm{OH}$ $+0.1 \mathrm{~mol} \mathrm{~L}^{-1} \mathrm{HClO}_{4}$ solution for PtLa/C $(50: 50)$ electrocatalysts. P-polarized light; resolution: $8 \mathrm{~cm}^{-1} ; E_{\text {ref }}=0.05 \mathrm{~V}$.

of acetaldehyde are the $\mathrm{C}=\mathrm{O}$ stretch (in the region of the signal at $1715 \mathrm{~cm}^{-1}$ ) and the symmetric $\mathrm{CH}_{3}$ deformation (in the region of the signal at $1354 \mathrm{~cm}^{-1}$ ). These bands can be then strongly overlapped with those of acetic acid. Assuming that the dual-path mechanism is acting for ethanol electrooxidation, $\mathrm{CO}_{2}$ and acetic acid can be considered as representative of the two reactions pathways (acetaldehyde is produced in the same route as acetic acid).

The acetic acid $\left(1278 \mathrm{~cm}^{-1}\right)$ and $\mathrm{CO}_{2}\left(2343 \mathrm{~cm}^{-1}\right)$ productions can be followed integrating their characteristic bands from the spectra in Figure 3 and plotting the result as a function of the potential. The integrated intensity values are given in Figures 4 and 5, respectively. The same procedure for spectra collection has been followed with PtLa/C (30:70) and $\mathrm{Pt} / \mathrm{C}$, and the results for their integration are also included in Figures 4 and 5.

The bands at 2343 and $1278 \mathrm{~cm}^{-1}$ in Figures 4 and 5 follow similar potential dependences, increasing the intensity as the sample potential is set more positive. It is also observed that the amount of both acetic acid and $\mathrm{CO}_{2}$ rises with the increment of La oxides/hidroxides content in the catalyst. However, some differences are apparent between the two $\mathrm{PtLa} / \mathrm{C}$ electrocatalysts and have to be remarked.

In general, the onset electrooxidation potential observed in the CVs in Figure 1 is related to the onset in the $\mathrm{CO}_{2}$ production (Figure 5) in all catalysts, whereas the formation of acetic acid starts at more positive potentials (Figure 4). This result suggests that it is necessary that adsorbed species initiate their oxidation to $\mathrm{CO}_{2}$ in order to liberate $\mathrm{Pt}$ sites, where ethanol molecules from the solution can further react and produce acetaldehyde and acetic acid. Although the onset potentials for both $\mathrm{CO}_{2}$ and acetic acid are similar for the three catalysts studied, from a detailed inspection of Figures 4 and 5, it is clearly observed a faster increase in the production of both $\mathrm{CO}_{2}$ and acetic acid in the presence of

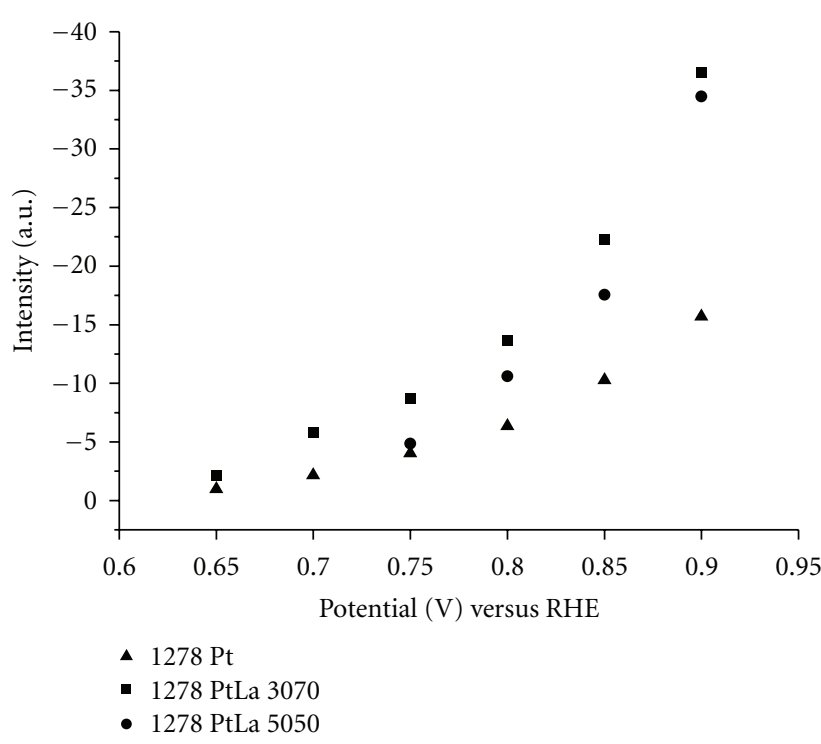

FIgURE 4: Potential dependence of the integrated band intensity $\left(1278 \mathrm{~cm}^{-1}\right)$ from Figure 3 corresponding to acetic acid, for $\mathrm{Pt} / \mathrm{C}$, $\mathrm{PtLa} / \mathrm{C}(50: 50)$, and PtLa/C (30:70) electrocatalysts.

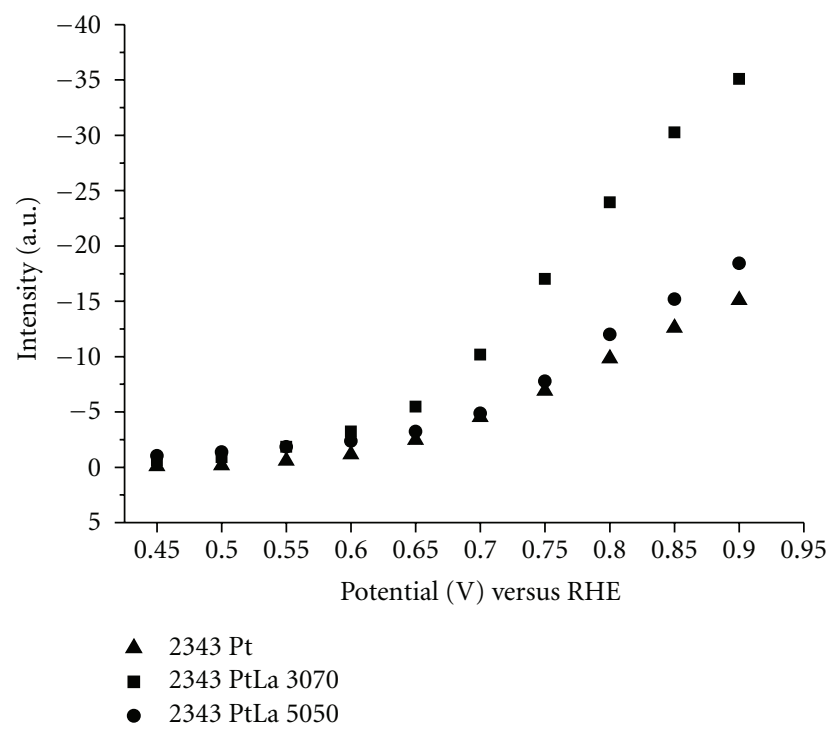

FIGURE 5: Potential dependence of the integrated band intensity $\left(2343 \mathrm{~cm}^{-1}\right)$ from Figure 3 corresponding to $\mathrm{CO}_{2}$, for $\mathrm{Pt} / \mathrm{C}, \mathrm{PtLa} / \mathrm{C}$ (50:50), and PtLa/C (30:70) electrocatalysts.

La oxides/hydroxides. In the case of Pt: La 50:50, the higher currents observed in Figure 1 with respect to Pt are due to the formation of higher amounts of acetic acid (Figure 4). For $\mathrm{Pt}$ : La $30: 70$, both $\mathrm{CO}_{2}$ (Figure 5) and acetic acid (Figure 4) productions are enlarged with respect to $\mathrm{Pt}$, but mainly $\mathrm{CO}_{2}$ when compared with PtLa 50:50. Therefore, it seems that initially the presence of La oxides/hydroxides contributes to enhancing the catalytic activity facilitating the bulk ethanol reaction; but increasing its content in the catalyst, also the electrooxidation of adsorbed intermediates to $\mathrm{CO}_{2}$ (and, therefore, the cleavage of the ethanol molecule) is favoured. 
To produce $\mathrm{CO}_{2}$ or $\mathrm{CH}_{3} \mathrm{COOH}, \mathrm{CH}_{3} \mathrm{CH}_{2} \mathrm{OH}$ needs at least a second oxygen atom. The reaction mechanism must involve some form of adsorbed oxygen species, which probably come from La oxides/hidroxides in addition to $\mathrm{PtOH}$ from water splitting. Although there is an evident rise in the performance of the catalyst with the increment of La oxides/ hidroxides content, this is mainly due to a faster oxidation of bulk ethanol to acetic acid, that is, without breaking the $\mathrm{C}-\mathrm{C}$ bond. However, it is also shown that with appropriate amounts of La oxides/hydroxides also the efficiency to $\mathrm{CO}_{2}$ (and, therefore, the cleavage of the molecule) can be enhanced.

\section{Conclusions}

The combination of electrochemical and spectroscopic techniques has allowed a comparative analysis of the behaviour of Pt/C, PtLa/C (50:50) and PtLa/C (30:70) electrocatalysts towards ethanol electrooxidation. A significant increase of performance was observed with the increment of La oxides/ hidroxides content, indicating that the addition of La species improves the activity of $\mathrm{Pt}$ for this reaction. FTIR results show that higher amounts of acetic acid are produced during ethanol oxidation at PtLa/C $(50: 50)$. Also the formation of $\mathrm{CO}_{2}$ is favoured if the La oxides/hydroxides content is raised to Pt : La 30:70, and, therefore, the presence of these compounds as oxygen source can favour both bulk alcohol reactions (acetic acid formation) and adsorbed species oxidation $\left(\mathrm{CO}_{2}\right.$ production).

The onset for ethanol oxidation is observed at $0.50 \mathrm{~V}$, that is, in the potential range used for a DAFC. The enhancement of activity towards alcohol electrooxidation in this potential region due to the addition of $\mathrm{La}$ oxides/hidroxides to $\mathrm{Pt}$ opens a possibility to utilize these materials as electrocatalysts for these devices. However, the detection of representative amounts of acetic acid clearly indicates that the $\mathrm{C}-\mathrm{C}$ bond is not completely broken and further optimization of the catalysts is needed to improve the energy efficiency of ethanol electrooxidation.

\section{Acknowledgments}

The authors thank FAPESP (Process 03/03127-0), CNPq (CTENERG 504793/2004-0), CAPES (Process 3982-07-6), MICINN (MAT2008-06631-C03-02), and ACIISI (PI2007/ 023) for the financial support.

\section{References}

[1] G. Mul and A. S. Hirschon, "Effect of preparation procedures on the activity of supported palladium/lanthanum methanol decomposition catalysts," Catalysis Today, vol. 65, no. 1, pp. 69-75, 2001.

[2] J. Petryk and E. Kolakowska, "Cobalt oxide catalysts for ammonia oxidation activated with cerium and lanthanum," Applied Catalysis B, vol. 24, no. 2, pp. 121-128, 2000.

[3] S. Irusta, L. M. Cornaglia, and E. A. Lombardo, "Hydrogen production using Ni-Rh on La," Journal of Catalysis, vol. 210, no. 1, pp. 7-16, 2002.
[4] O. V. Manoilova, S. G. Podkolzin, B. Tope et al., "Surface acidity and basicity of La," Journal of Physical Chemistry B, vol. 108, no. 40, pp. 15770-15781, 2004.

[5] S. J. Huang, A. B. Walters, and M. A. Vannice, "Adsorption and decomposition of NO on lanthanum oxide," Journal of Catalysis, vol. 192, no. 1, pp. 29-47, 2000.

[6] M. Traykova, N. Davidova, J. S. Tsaih, and A. H. Weiss, "Oxidative coupling of methane-the transition from reaction to transport control over La," Applied Catalysis A, vol. 169, no. 2, pp. 237-247, 1998.

[7] H. Vidal, S. Bernal, R. T. Baker, G. A. Cifredo, D. Finol, and J. M. Rodríguez-Izquierdo, "Catalytic behavior of lanthana promoted Rh/SiO," Applied Catalysis A, vol. 208, no. 1-2, pp. 111$123,2001$.

[8] L. M. Cornaglia, J. Múnera, S. Irusta, and E. A. Lombardo, "Raman studies of Rh and Pt on La," Applied Catalysis A, vol. 263, no. 1, pp. 91-101, 2004.

[9] W. Zhou, Z. Zhou, S. Song et al., "Pt based anode catalysts for direct ethanol fuel cells," Applied Catalysis B, vol. 46, no. 2, pp. 273-285, 2003.

[10] A. O. Neto, A. Y. Watanabe, M. Brandalise et al., "Preparation and characterization of Pt-Rare Earth/C electrocatalysts using an alcohol reduction process for methanol electro-oxidation," Journal of Alloys and Compounds, vol. 476, no. 1-2, pp. 288291, 2009.

[11] G. García, J. A. Silva-Chong, O. Guillén-Villafuerte, J. L. Rodríguez, E. R. González, and E. Pastor, "CO tolerant catalysts for PEM fuel cells. Spectroelectrochemical studies," Catalysis Today, vol. 116, no. 3, pp. 415-421, 2006.

[12] S. Song and P. Tsiakaras, "Recent progress in direct ethanol proton exchange membrane fuel cells (DE-PEMFCs)," Applied Catalysis B, vol. 63, no. 3-4, pp. 187-193, 2006.

[13] A. O. Neto, R. R. Dias, M. M. Tusi, M. Linardi, and E. V. Spinacé, "Electro-oxidation of methanol and ethanol using $\mathrm{PtRu} / \mathrm{C}, \mathrm{PtSn} / \mathrm{C}$ and $\mathrm{PtSnRu} / \mathrm{C}$ electrocatalysts prepared by an alcohol-reduction process," Journal of Power Sources, vol. 166, no. 1, pp. 87-91, 2007.

[14] E. V. Spinacé, L. A. Farias, M. Linardi, and A. O. Neto, "Preparation of $\mathrm{PtSn} / \mathrm{C}$ and $\mathrm{PtSnNi} / \mathrm{C}$ electrocatalysts using the alcohol-reduction process," Materials Letters, vol. 62, no. 14, pp. 2103-2106, 2008.

[15] E. Antolini, J. R. C. Salgado, L. G. R. A. Santos et al., "Carbon supported Pt-Cr alloys as oxygen-reduction catalysts for direct methanol fuel cells," Journal of Applied Electrochemistry, vol. 36, no. 3, pp. 355-362, 2006.

[16] Y. Bai, J. Wu, X. Qiu et al., "Electrochemical characterization of $\mathrm{Pt}-\mathrm{CeO}_{2} / \mathrm{C}$ and Pt-Ce $\mathrm{Zr}_{1-x} \mathrm{O}_{2} / \mathrm{C}$ catalysts for ethanol electrooxidation," Applied Catalysis B, vol. 73, no. 1-2, pp. 144-149, 2007.

[17] E. V. Spinacé, A. O. Neto, T. R. R. Vasconcelos, and M. Linardi, "Electro-oxidation of ethanol using PtRu/C electrocatalysts prepared by alcohol-reduction process," Journal of Power Sources, vol. 137, no. 1, pp. 17-23, 2004.

[18] E. V. Spinacé, A. O. Neto, T. R. R. Vasconcelos, and M. Linardi, Brazilian Patent INPI-RJ, PI0304121-2, 2003.

[19] F. Colmati, W. H. Lizcano-Valbuena, G. A. Câmara, E. A. Ticianelli, and E. R. Gonzalez, "Carbon monoxide oxidation on Pt-Ru electrocatalysts supported on high surface area carbon," Journal of the Brazilian Chemical Society, vol. 13, no. 4, pp. 474-482, 2002.

[20] K. W. Lux and E. J. Cairns, "Lanthanide-platinum intermetallic compounds as anode electrocatalysts for direct ethanol PEM fuel cells," Journal of the Electrochemical Society, vol. 153, no. 6, pp. A1132-A1138, 2006. 
[21] T. A. B. Santoro, A. O. Neto, R. Chiba, E. S. M. Seo, and E. G. Franco, "Characterization of proton exchange membrane fuel cell cathode catalysts prepared by alcohol-reduction process," Materials Science Forum, vol. 660-661, pp. 94-99, 2010.

[22] X. Wang, M. Wang, H. Song, and B. Ding, "A simple sol-gel technique for preparing lanthanum oxide nanopowders," Materials Letters, vol. 60, no. 17-18, pp. 2261-2265, 2006.

[23] T. A. B. Santoro, C. A. L. G. de O. Forbicini, A. O. Neto et al., "Synthesis of PtLa/C catalysts for polymer electrolyte membrane fuel cells," in Proceedings of the 1st Simposium Ibérico de Hidrógeno, Pilas de Combustible y Baterías Avanzadas (HYCELTEC '08), Bilbao, Spain, 2008.

[24] C. Xu, R. Zeng, P. K. Shen, and Z. Wei, "Synergistic effect of $\mathrm{CeO}_{2}$ modified Pt/C catalysts on the alcohols oxidation," Electrochimica Acta, vol. 51, no. 6, pp. 1031-1035, 2005.

[25] L. M. Cornaglia, J. Múnera, S. Irusta, and E. A. Lombardo, "Raman studies of $\mathrm{Rh}$ and $\mathrm{Pt}$ on $\mathrm{La}_{2} \mathrm{O}_{3}$ catalysts used in a membrane reactor for hydrogen production," Applied Catalysis A, vol. 263, no. 1, pp. 91-101, 2004.

[26] A. O. Neto, L. A. Farias, R. R. Dias, M. Brandalise, M. Linardi, and E. V. Spinacé, "Enhanced electro-oxidation of ethanol using $\mathrm{PtSn} / \mathrm{CeO}_{2}-\mathrm{C}$ electrocatalyst prepared by an alcohol-reduction process," Electrochemistry Communications, vol. 10, no. 9, pp. 1315-1317, 2008.

[27] T. Iwasita, B. Rasch, E. Cattaneo, and W. Vielstich, "A sniftirs study of ethanol oxidation on platinum," Electrochimica Acta, vol. 34, no. 8, pp. 1073-1079, 1989. 


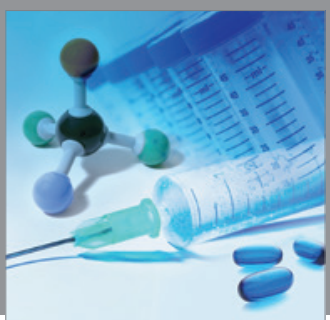

International Journal of

Medicinal Chemistry

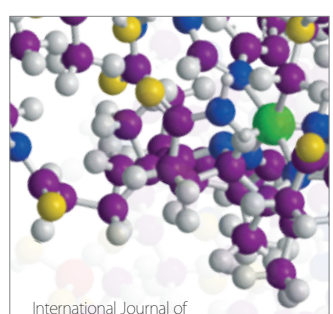

Carbohydrate Chemistry

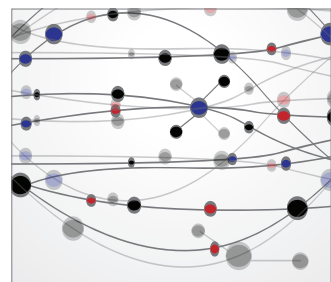

The Scientific World Journal
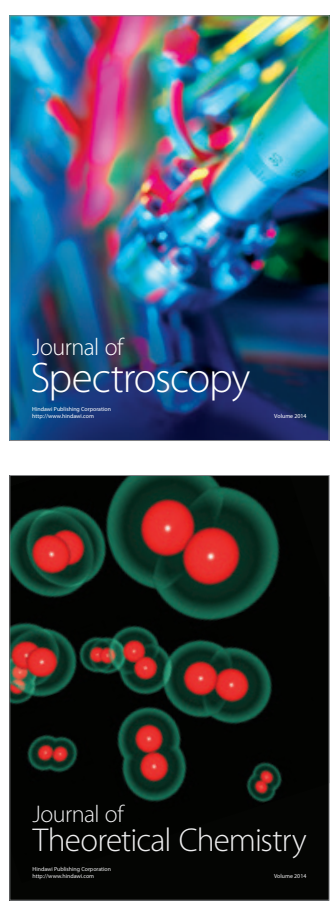
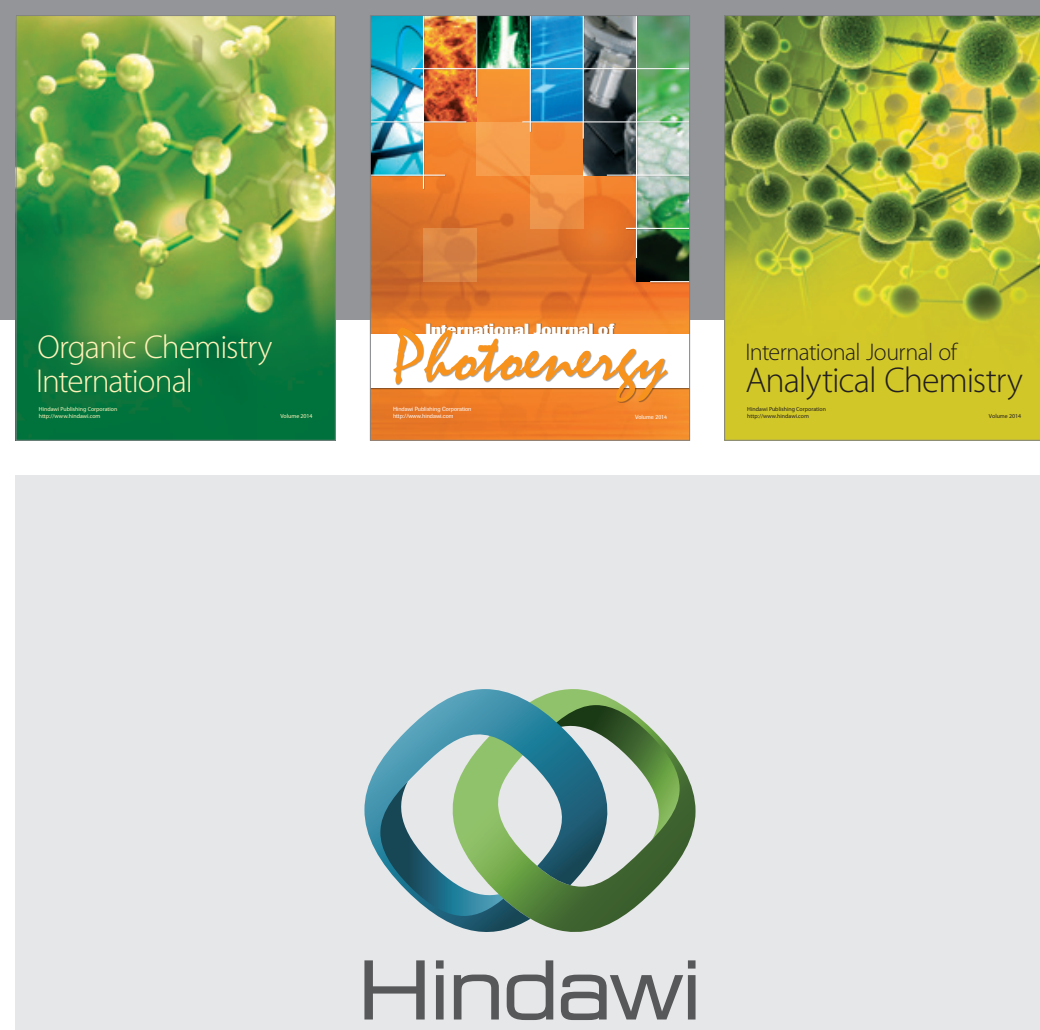

Submit your manuscripts at

http://www.hindawi.com
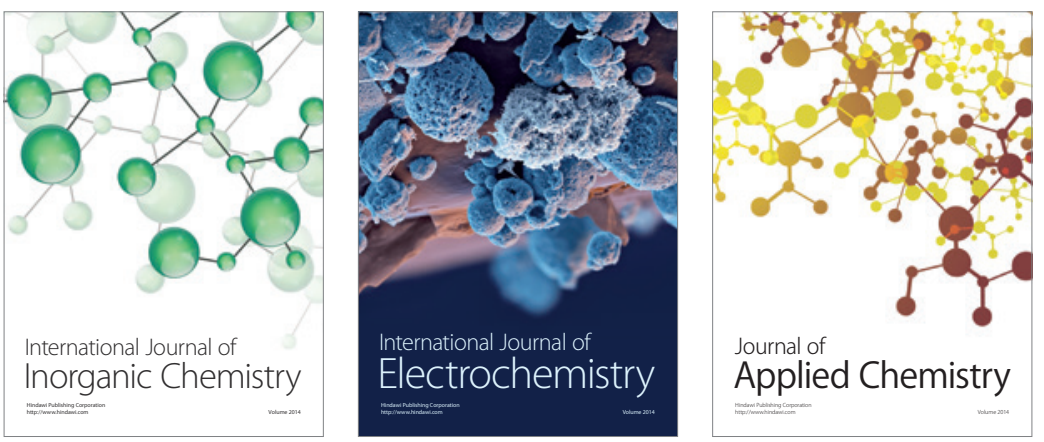

Journal of

Applied Chemistry
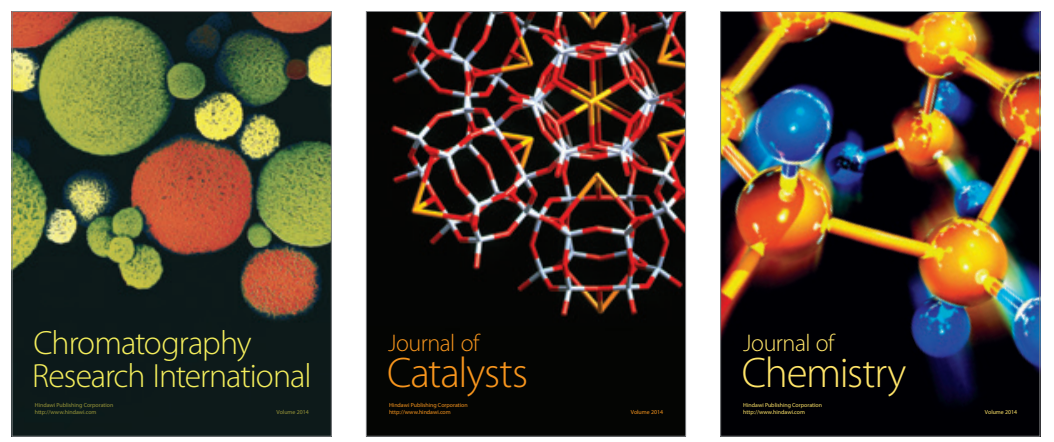
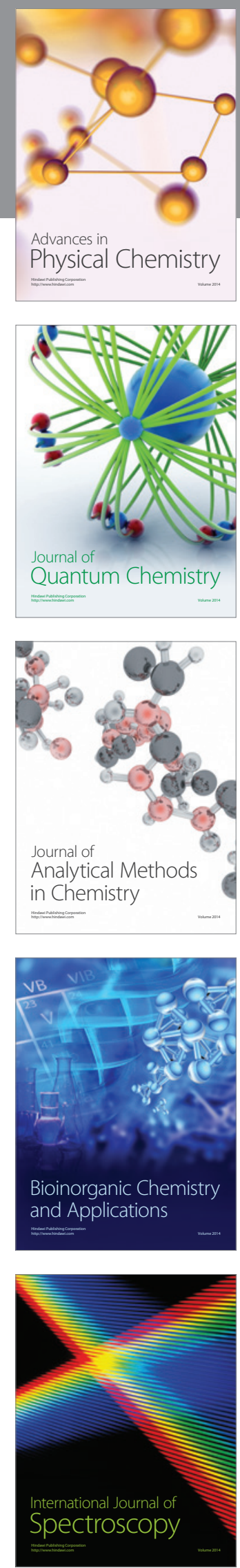